\title{
FDI and Economic Growth Linkages in Malaysia
}

\author{
Nor Jana Salim* \\ Rajmi Mustaffa \\ Nor Jawanees Ahmad Hanafiah \\ Universiti Teknologi MARA \\ *Email: norja049@tganu.uitm.edu.my
}

Doi:10.5901/mjss.2015.v6n4s2p652

\begin{abstract}
The primary concern of the present study is to re-examine the relationship between Foreign Direct Investment (FDI) and Gross Domestic Product (GDP) in Malaysia when savings-investment gap recorded a surplus in the late 90's. It focuses on the transition period from shortage to surplus in savings, which has not been given attention by many previous studies, especially in Malaysia. Using time series analysis, the quarterly data consisting of FDI, GDP and trade openness from year 2000 until 2010 were carefully analyzed and Autoregressive Distributed Lag (ARDL) model for integration and Granger Causality tests were employed. The results revealed that all the variables used in the study are co-integrated in the long run. Furthermore, the results also show that there exists the unidirectional Granger Causality from FDI to GDP. Thus, this study concludes that Malaysia still relies on FDI to boost its economic growth even though there is a surplus in savings-investment gap.
\end{abstract}

Keywords: Autoregressive Distributed Lag (ARDL); FDI; GDP; co-integrated; surplus; boost; investment;

\section{Introduction}

A survey done by the World Bank in 1993 found that countries with high savings rate have grown faster than those with low savings rate. Besides, Foreign Direct Investment (FDI) also plays a very significant role in increasing the production frontier of developing countries that generally suffer from a shortage of capital (Paul, 2008). FDI can increase domestic capital formation, augment host country's stocks of technology and managerial know how, improve access to export markets and stabilize external financing (Lehmann, 2002). Due to a deficit in savings-investment during the period from 1986 to 1998, Malaysia with no exception had to rely on FDI for almost three decades (Ismail, 2000). Kew (2003) proved empirically that Malaysia experienced FDI-Led-Growth during the period prior to 1998. Fortunately, beginning 1997 the savings-investment gap showed a surplus. However, in 2000s the FDI performance had been unstable and turned into a downward trend. The Asian Financial Crisis 1997 with a few other crises such as the electronic production downturn in 2001-2000, competition from low cost manufacturing countries in 2004 and 2008 credit crunch also had resulted in a significant decline in the flows of FDI to Malaysia. This has led to an interesting question of how FDI can stimulate the economic growth of Malaysia.

Thus, it has become the aim of this study to re-examine the role of FDI as a leading indicator in accelerating the economic growth of Malaysia after it has experienced a surplus in savings. It mainly seeks to reveal the long-run and the short-run relationships between FDI and economic growth for the period from year 2000 until year 2010 as well as to see causal relationship between both of the variables. As such, the findings will significantly contribute to the literature of the relationship between FDI and economic growth and provide some form of empirical data to others who are interested to conduct future research in this area.

\section{Literature Review}

Previous studies have revealed mixed findings on the causal relationship between FDI and economic growth which are bi-directional, unidirectional or no causal relationship. There was a two-way causality running between output growth and FDI in a study by Shan et al. (1997) in China, the largest recipient of FDI among developing countries. Sridharan et al. (2009) found that two sets of causal link for BRICS (Brazil, Russia, India, China, South Africa) after financial liberalization took place. Firstly, the economic growth had bi-directionally promoted FDI in Brazil, Russia and South Africa whilst FDI 
had unidirectionally promoted the economic growth in India and China. Besides, Omisakin et al.(2009) revealed a unidirectional causal relationship running from foreign direct investment to output in Nigeria after the adoption of structural adjustment policy in 1986. Another unidirectional causality running from FDI to Gross Domestic Product (GDP) was discovered by Kundan and Gu (2010) in Nepal, one of the most liberalized countries in South Asian region from 1980 to 2006. Other researchers have found weak or no evidence of the relationship between FDI and economic growth. Among others were De Mello (1999), who studied on samples of 32 developed and developing countries, Magnus and Fosu (2008) who conducted a study in Ghana using time series from 1970-2000, and also Shimul et al. (2009) who conducted a study in Bangladesh from 1973 until 2007. A few studies in Malaysia have also revealed mixed findings on these relationships due to different time frames and methodological approaches. Khor (2001) found a bidirectional relationship using time series data and Granger Causality test. Pradhan (2008) confirmed that FDI had promoted the economic growth of Malaysia from 1970 to 2004. However, no such evidence was found by Karimi and Yusop (2009) who used Toda-Yamamoto test and the Autoregressive Distributed Lag (ARDL) covering the period from 1970 to 2005. Pradhan (2009) shared similar findings using panel data for the period from 1970 until 2007 in five ASEAN countries including Malaysia. In short, thereview of the past literature indicates that more research should be conducted in order to gain more conclusive evidence on the relationship between FDI and the economic growth in Malaysia.

\section{Methodology}

This study examined quarterly time series data from year 2000:Q1 until 2010:Q4. The variables involved were GDP, a proxy for economic growth, Foreign Direct Investment Inflows into Malaysia (INFDI) and Trade Openness (TRADE), the sum of export and import values of the GDP. All data were extracted from Yearbook of Department of Statistics Malaysia and its website.

The ARDL bounds testing of co-integration approach developed by Pesaran et al. (2001) was employed as this bounds testing procedure does not require the variables included in the model for unit roots to undergo pre-testing (Narayan \& Narayan, 2006). It is applicable irrespective of whether the variables in the models are I(0), I(1) or mutually co-integrated. Furthermore, the test is also found to be relatively more efficient for data from small-sized samples.

The existence of long-run relationship among the variables in the system was tested by estimating (1) using ordinary least square method and conducting an F-test for the joint significance of the coefficients of the lagged level of the variables.

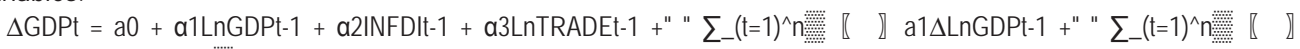

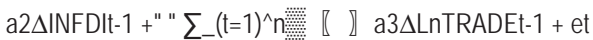

The short-run relationship can be obtained by estimating (2):

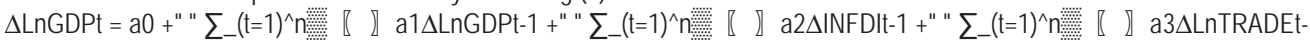
$1+\mathrm{ECMt}-1+$ et

\section{Results and Discussion}

Unit Root Test is not required for co-integration testing using ARDL approach but it is necessary for the purpose of determining the underlying properties of the process that generate these time series.

Table 1. Augmented Dickey Fuller (ADF) Unit Root Test

\begin{tabular}{|c|c|c|c|c|}
\hline Variable & Constant Level & 1st Diff. & Trend Level & 1st Diff. \\
\hline LnGDP & 0.102 & $-4.461^{\star \star \star}$ & -2.345 & $-4.405^{\star \star \star}$ \\
\hline INFDI & $-5.086^{\star \star *}$ & $-12.440 * * *$ & $-5.747^{\star \star \star}$ & $-12.352^{* * *}$ \\
\hline LnTRADE & 0.780 & $-3.787^{\star \star \star}$ & 1.034 & $-4.544^{\star \star \star}$ \\
\hline
\end{tabular}

Table 1 shows that both LnGDP and LnTRADE were clearly integrated of order one, I(1), while INFDI was integrated of order zero I(0). 
Table 2. Philip Perron (PP) Unit Root Test

\begin{tabular}{|ccccc|}
\hline Variable & Constant Level & 1st Diff. & Trend Level & 1st Diff. \\
\hline LnGDP & 0.366 & $-7.987^{\star \star *}$ & $-3.219^{\star}$ & $-7.924^{\star \star *}$ \\
INFDI & $-5.419^{*}$ & $-14.528^{\star \star *}$ & $-5.879^{\star \star *}$ & $-14.501^{\star \star *}$ \\
LnTRADE & $-5.446^{*}$ & $-16.789^{\star \star *}$ & $-5.629^{\star * *}$ & $-32.855^{\star \star *}$ \\
\hline
\end{tabular}

***significant at $1 \%$; *significant at $10 \%$

Next, Table 2 shows INFDI and LnTRADE were integrated of order zero, I(0), while LnGDP was integrated of order one, I(1), with constant but integrated of order zero, I(0), with trend. Thus, it can be concluded that ARDL approach is the most appropriate method of estimation since the variables are the mixture of $\mathrm{I}(0)$ and I(1) order of integration.

\subsection{Co-integration test}

Table 3 reports the result of ARDL co-integration test with the critical value given in Table 4.

Table 3. ARDL Bound Testing (F-Test)

\begin{tabular}{|c|c|c|}
\hline Model & F-Statistic & Outcome \\
\hline$F_{\text {LnGDP }(\text { LnGDP|INFDI, LnTRADE) }}$ & 6.60 & Co-Integrated \\
\hline $\mathrm{F}_{\text {INFDD,(INFDI|LnGDP, LnTRADE) }}$ & 2.11 & Not Co-integrated \\
\hline FLnTRADE(LnTRADE|INFDI,LnGDP) & 4.28 & Co-Integrated \\
\hline
\end{tabular}

Table 4. Asymptotic Critical Value

\begin{tabular}{|lcc|}
\hline & Lower Bound & Upper Bound \\
\hline 1\% Significant Level & 5.15 & 6.36 \\
5\% Significant Level & 3.79 & 4.85 \\
10\% Significant Level & 3.17 & 4.14 \\
\hline
\end{tabular}

The null hypothesis of no co-integration, regardless of whether the variables are I(0), I(1) or the mixture of both is rejected when LnGDP and LnTRADE are the dependent variables at $1 \%$ and $10 \%$ level of significance respectively. This means that there exists a long run relationship among the variables when GDP and Trade Openness are the dependent variables. However, the result is inconclusive when INFDI is the dependent variable.

\subsection{Long-run relationship}

Based on the result of co-integration test, long-run coefficient is estimated by normalizing on real GDP. Table 5 shows that the result was not robust as both NFDI and LnTRADE elasticities were statistically insignificant. However, FDI inflows and Trade Openness were positively related to GDP and this finding is consistent with other previously conducted studies.

Table 5. Long-Run Elasticities

\begin{tabular}{|cccc|}
\hline Regressor & Coefficient & Standard Error & T-Ratio (Prob.) \\
\hline INFDI & $0.911 \mathrm{E}-4$ & $0.907 \mathrm{E}-4$ & $1.004(0.322)$ \\
LnTRADE & 0.248 & 1.092 & $0.227(0.822)$ \\
INPT & 9.517 & 10.487 & $0.908(0.371)$ \\
\hline
\end{tabular}

\subsection{ECM analysis (short-run relationship)}

The ECM (Error Correction mechanism) coefficient shows how quickly variables return to equilibrium. 
Table 6. Short-Run Elasticities

\begin{tabular}{|cccc|}
\hline Regressor & \multicolumn{3}{c|}{ Lag Order } \\
\hline & 0 & 1 & 2 \\
$\Delta$ InGDP & & $0.077(0.686)$ & $-0.636\left(5.899^{\star \star \star}\right)$ \\
IINFDI & $0.230 E-5\left(1.963^{\star \star}\right)$ & - & - \\
InTRADE & $-0.038\left(-2.145^{\star \star}\right)$ & - & - \\
$\Delta$ INPT & $0.240(0.531)$ & - & - \\
ECM $(-1)$ & & $-0.025226(-0.92151)$ & \\
\hline
\end{tabular}

Table 6 shows that although the one-lagged error correction term (ECM) is found to have the expected negative sign that is $\operatorname{ECM}(-1)=-0.025226$, it is not significant enough to confirm the existence of short run co-integration among the variables. This result is also consistent with the study done by Omisakin et al. (2009).

\subsection{Diagnostic test}

To ascertain the goodness of the ARDL model, the diagnostic test and the stability test were conducted. Table 7 shows that the model generally passed all the diagnostic tests namely the Breusch-Godfrey Serial Correlation LM test, JacqueBerra normality test, Ramsey RESET stability test and ARCH test in the first stage. None of the computed statistics was significant which implies that there is no problem of heteroscedasticity, normality, and functional form in the model.

Table 7. Diagnostic Checking for ARDL Model

\begin{tabular}{|cc|}
\hline Diagnostic Tests & ARDL(3,0,1) \\
\hline LM Test & $5.951(0.203)$ \\
Ramsey RESET & $2.059(0.151)$ \\
Jacque-Berra & $3.625(0.163)$ \\
Heteroscedasticity & $0.046(0.835)$ \\
\hline
\end{tabular}

\subsection{Stability test}

Stability of the long-run and short-run parameters in the model is also tested by using the Cumulative Sum (CUSUM) and the Cumulative Sum of Squares (CUSUMSQ) tests. Since the results of CUSUM and CUSUMSQ tests proposed by Brown, Durbin, \& Evans (1975) must stay within a 5\% level (portrayed by two straight lines), the results of this study indicate significant and stable relation among the variables under consideration. Thus, the model is stable and correctly specified in Figures 1 and 2.

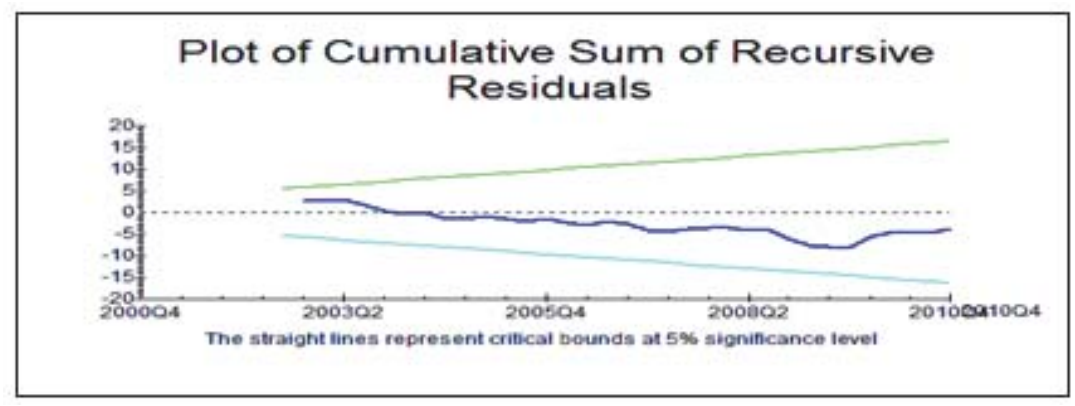

Figure 1. Cumulative Sum (CUSUM) Stability Test 


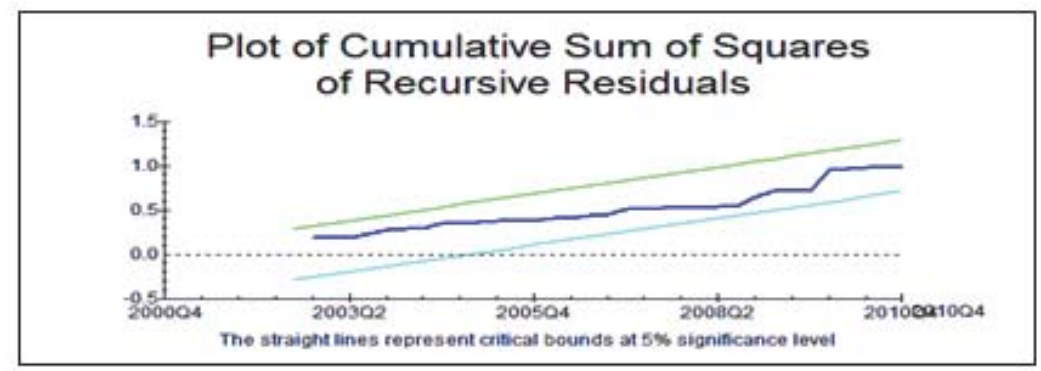

Figure 2. Cumulative Sum of Square (CUSUMSQ) Stability Test

\subsection{Granger causality test}

Table 8 shows that the null hypothesis of INFDI does not Granger cause GDP is rejected at 5\% level of significance with 41 observations or after lag 3. However, the null hypothesis of GDP does not Granger cause INFDI cannot be rejected. Therefore, Granger causality test indicates that there is a unidirectional causality running from INFDI to GDP. This implies that FDI inflows stimulate the economic growth (GDP) after the third quarter of the period under study. On the other hand, since there is no causality running from GDP to INFDI, it signifies that GDP does not influence the inflows of FDI in Malaysia.

Table 8. Granger causality test

\begin{tabular}{|lccc|}
\hline Null Hypothesis & Observations & F-Statistic & Probability \\
\hline INFDI does not Granger cause GDP & 41 & 4.139 & $0.013^{\star *}$ \\
GDP does not Granger cause INFDI & 41 & 1.270 & 1.270 \\
\hline
\end{tabular}

\section{Conclusion}

The findings of this study indicate that the variables under study namely economic growth and FDI inflows in Malaysia are bound together in the long run. The results also show positive influence of FDI inflows on the economic growth although its elasticity is insignificant. Significantly, a unidirectional causality which runs from FDI inflows to economic growth can be a clear indicator to the policy makers that the Malaysian economy and its growth are dependent on FDI.

Another important lesson that could be learned from this study is Malaysia needs to thoroughly review its trade and other policies which can retain existing FDI from shifting away their productions and strengthen efforts to secure new FDI. Hence, excessive bureaucratic procedures should be reduced and transparent trade and investments strategies should be adopted to attract more FDI and simultaneously advance the economic development of the country. Besides, corporate and income tax reduction should be given attention as Malaysia's corporate tax rate is among the highest in Association of Southeast Asian Nations (ASEAN) region.

In addition, Malaysia also needs to improve her dynamic package to attract FDI such as quality human capital, infrastructure, Information And Communications Technology (ICT) and good governance. All in all, results of this research may not provide final conclusion on the relationship between FDI and GDP in Malaysia but they should be cautiously interpreted. In order to get more robust and conclusive results, it is recommended that future research should include larger data set, add more variables or use other proxies of economic growth.

Another important lesson that could be learned from this study is Malaysia needs to thoroughly review its trade and other policies which can retain existing FDI from shifting away their productions and strengthen efforts to secure new FDI. Hence, excessive bureaucratic procedures should be reduced and transparent trade and investments strategies should be adopted to attract more FDI and simultaneously advance the economic development of the country. Besides, corporate and income tax reduction should be given attention as Malaysia's corporate tax rate is among the highest in Association of Southeast Asian Nations (ASEAN) region.

In addition, Malaysia also needs to improve her dynamic package to attract FDI such as quality human capital, infrastructure, Information And Communications Technology (ICT) and good governance. All in all, results of this research 
may not provide final conclusion on the relationship between FDI and GDP in Malaysia but they should be cautiously interpreted. In order to get more robust and conclusive results, it is recommended that future research should include larger data set, add more variables or use other proxies of economic growth.

\section{Acknowledgement}

The authors are indebted to the Research Management Institute (RMI), UiTM Shah Alam, Malaysia for funding this research through the Excellence Fund.

\section{References}

Brown, R. L., Durbin, J., \& Evans, J. M. (1975). Techniques for testing the constancy of regression relationships over time. Journal of the Royal Statistical Society, 37, 149-192.

De Mello, L. R. (1999). Foreign direct investment led growth: Evidence from time series and panel data. Oxford Economics Papers, 51, 133-151.

Ismail, R. (2000). Faktor pertumbuhan ekonomi. In: N. A. Idris, \& A. R. Dan (Eds.), Teori pertumbuhan dan pembangunan ekonomi (pp.103-124). Selangor: Penerbit Universiti Kebangsaan.

Karimi, M. S., \& Yusop, Z., (2009), FDI and economic growth in Malaysia. [Online] Available: http://mpra.ub.uni-muenchen.de/14999/1/ MPRA_paper_14999.pdf

Kew, W. C. (2003). FDI, exports and macroeconomics performance in Malaysia: A causality analysis. (Master dissertation, Universiti of Malaya, 2003).

Khor, C. B. (2001). Foreign direct investment and economic growth. (Masters dissertation, Universiti Utara Malaysia, 2001).

Kundan, P. M., \& Gu, Q. (2010). A time series analysis of foreign direct investment and economic growth: A case study of Nepal. International Journal of Business and Management, 5, 144-148.

Lehmann, A., (2002), Foreign direct investment in emerging markets: Income, repatriations and financial vulnerabilities. [Online] Available: http://www.imf.org/external/pubs/tt/wp/2002/wp0247.pdf

Magnus, F. J., \& Fosu, O. A. (2008). Bivariate causality analysis between FDI inflows and economic growth in Ghana. International Research Journal of Finance and Economics,15, 144-148.

Narayan, P., \& Narayan, S. (2006). Savings behaviour in Fiji: An empirical assessment using the ARDL Approach to cointegration. International Journal of Social Economics, 33, 468-480.

Omisakin, O., Adeniyi, O., \& Omojolabi, A. (2009). Foreign direct investment, trade openness and growth in Nigeria. Journal of Economic Theory, 3, 13-18.

Paul, R. K. (2008). International economics: Theory and policy. (8th ed.). Pearson Education India.

Pesaran, M. H., Shin, Y., \& Smith, R. (2001). Bound testing approaches to the analysis of level relationships. Journal of Applied Econometrics, 16, 289-326.

Pradhan, R. P. (2008). Does economic growth promote foreign direct investment? Evidence from India and Malaysia. South Asian Journal of Management, 15, 7-23.

Pradhan, R. P. (2009). The FDI-led_growth hypothesis in ASEAN-5 countries: Evidence from cointegrated panel analysis. International Journal of Business and Management, 4, 153-158.

Shan, J., Tian, G. G., \& Sun, F., (1997), The FDI-led growth hypothesis: Further econometric evidence from China. [Online] Available: https://digitalcollections.anu.edu.au/bitstream/1885/40394/3/ce97-2.pdf

Shimul, S. N., Abdullah, S., \& Siddiqua, S. (2009). An examination of FDI and growth nexus in Bangladesh: Engle granger and bound testing cointegration approach. BRAC University Journal, 6, 69-76.

Sridharan, P., Vijayakumar, N., \& Chandra, K. (2009). Causal relationship between foreign direct investment and growth: Evidence from BRICS countries. International Business Research, 2, 198-203. 